\author{
Pavel Burě̌ \\ JUDr., PhD., D.E.A, Senior lecturer, Palacky University, Faculty of Law
}

pavel.bures@upol.cz

\title{
RECENT DEVELOPMENTS OF INTERNATIONAL LAW COMMISSION WORK ON IMMUNITY OF STATE OFFICIALS FROM FOREIGN CRIMINAL JURISDICTION
}

\begin{abstract}
Immunity is a well bedded concept within international law and mainly within the principle of sovereign equality of states. There are different procedural implications of the concept of immunity - diplomatic and consular privileges and immunities, State jurisdictional immunities and also immunity of State officials from foreign criminal jurisdiction. The Article focuses on the latter one and portrays on recent developments of immunity of State officials from foreign criminal jurisdiction as it is elaborated by the UN International Law Commission ('ILC'). The author frames (in the introduction) the concept of immunity and especially the immunity of State officials and puts it in a large theoretical structure of international law and in the work of ILC. Then, he focuses his attention on the phenomenon of progressive development of international law (2) and how it is used with respect to the topic considerated by the ILC. He then presents main ILC conclusions regarding limitations and exceptions to immunity of State officials (3) and finally outlines latest development (4) of the ILC work dealing mainly with relationship between foreign criminal jurisdiction and international criminal jurisdiction and other procedural questions.
\end{abstract}


Keywords: Immunity of State Officials, International Law Commission, immunity exceptions, crimes under international law

\section{Introduction}

In international law, immunity as a procedural impediment to exercise jurisdiction lies within the principle of sovereign equality of states that has its procedural implication in the principle of par in parem non habet iurisdictionem. Currently, we may find different practical implications of this concept: diplomatic and consular privileges and immunities, immunities of officials of international organisations, State jurisdictional immunities, non-invocability of immunities for State officials before international criminal tribunals etc. The necessity to cope with the concept of immunity of state officials from foreign criminal jurisdiction on the international level arose in the late 90 s of the previous century. In the period of a certain political détente of a normally bi-polar world, ad hoc international criminal tribunals ${ }^{1}$ were created to prosecute State officials in special situations related mostly to international peace and security. ${ }^{2}$ Where there was no direct impact on international peace and security, the case was dealt with on national level. ${ }^{3}$ Nevertheless, specialists in the field of human rights, as well as NGO's or large public, drew attention to a more essential problem behind all those situations and condensed it in a saying 'Immunity means no impunity'. In the late nineties, worldwide opinion stressed that mass human rights violations perpetrated by high State officials cannot remain unpunished and that the capacity of the State official cannot be a procedural barrier for national or international criminal proceedings. Therefore, the process of the creation of a permanent international criminal tribunal (ICC) went hand in hand with a crystallization, petrification or 'uncovering' of rules governing immunity of State officials from foreign

1 International criminal tribunals for ex-Yugoslavia and Rwanda were created, as well as other internationalized or mixed criminal chambers (for Khmers in Cambodia, in Sierra Leona, in Iraq etc.).

2 UN Charter, Chapter VII.

3 It is interesting to note that before the creation of ICTR by the UN Security Council resolution, criminal investigation and proceedings have already been initiated thanks to the principle of universal jurisdiction before national courts in Belgium. The issue of immunity was not raised. 
criminal jurisdiction. The topic has been put on the agenda of the UN International Law Commission ('ILC' or 'the Commission') in 2007, and now, after more than ten years of work, the Commission has finished the process by adopting the finalized version of the draft on the first reading. ${ }^{4}$ This note depicts the developments of ILC work on the topic, focusing on the recent stages of the process. So, the Article will expose some historical background and key developments, as well as: (1), some doubts about methodological approach (2), exceptions and limitations to the basic rule on immunity (3), and the latest development presented in April 2020 (4). Immunity of State officials from foreign criminal jurisdiction before the ILC

The topic of immunity of State officials from foreign criminal jurisdiction has been scheduled on the long-term agenda of the Commission in 2006. However, it was not the first time that the Commission dealt with the subject matter. The ILC mentioned the topic of jurisdiction over foreign States and more precisely the issue of jurisdictional immunities of States [...] and their sovereigns ${ }^{5}$ already in 1949 in its Survey on International Law in relation to the work of codification. Subsequently, the issue of immunity of state officials was discussed by the Commission on other different occasions - not only during the preparation of the Draft Declaration on Rights and Duties of States which takes into account merely diplomatic officers; but also in the course of other codifications (Principles of international law recognized in the Charter of the Nürnberg Tribunal and in the Judgment of the Tribunal in 1950, Draft Code of Crimes against Peace and Security of Mankind in 1954 and in 1996) where the topic was developed somewhat further. The main principle concerning State officials derived from those documents is that the official capacity of individual who perpetrated crimes under international law or crimes against peace and security of mankind does not relieve him from criminal responsibility. Lastly, the topic was also discussed during the codification of jurisdictional immunities of States and their properties. The Convention adopted in 2004 understands under the term of States 'representatives of States acting in that capacity ${ }^{6}$ likewise. Nevertheless, the Convention specifies in its Article 3 that it is without

4 Due to the ongoing COVID-19 Pandemic, the General Assembly, decided that the seventy-second session of the ILC will be postponed to 2021. (Cf. https://legal.un.org/ ilc, accessed 28 June 2021).

5 A/CN.4/1/rev.1, 1949, para 50.

6 UN Convention on Jurisdictional Immunities of States and their Properties, Article 2 para 1, (iv). 
prejudice to privileges and immunities accorded under international law to head of States ratione personae. By saying that, it excludes automatically the topic of immunities of state officials from foreign criminal jurisdiction of its scope.

In 2007, the Commission appointed Mr. Roman Anatolevich Kolodkin as a Special rapporteur on the topic. Mr. Kolodkin, till the end of his membership in the Commission in 2011, prepared three reports. The preliminary report in 2008 sketched a basic outline of the issue of immunities of State officials from foreign criminal jurisdiction, such as sources, basic definition of immunity and jurisdiction, and delimitation of the scope of the topic (boundaries of the issue and persons covered). Kolodkin developed those subjects in the second and third reports (both in 2011). As his mandate finished in 2011, Mr. Kolodkin could not go further in the research of the topic. The task was then entrusted to Ms. Concepción Escobar Hernández. Ms. Hernández presented eight successive reports, the very last in April 2020 aiming to conclude the topic. The Special rapporteur also produced various draft Articles reflecting subjects considered in her reports. Some of her draft Articles have already been adopted by the Commission, others are still pending before the Drafting Committee; the adoption of those contained in her last report was postponed to 2021. The Draft Articles on immunities of State officials ${ }^{8}$ from foreign criminal jurisdiction should contain 18 Articles divided in four parts (Part One Introduction - displaying scope of the Draft Articles and definitions of terms, Part Two - Immunity ratione personae, Part Three - Immunity ratione materiae and Part Four - Procedural provisions and safeguards. ${ }^{9}$

7 For example, within the draft Article 2 on definitions, the definition of 'criminal jurisdiction' is still pending before the ILC Drafting Committee.

8 'State official' means any individual who represents the State or who exercises State functions (Draft Article 2, e) adopted by the ILC.

9 Cf. Annexes I - IV of the 8th report A/CN.4/739. 


\section{Methodological approach - or what is progressive development?}

The International law commission has been set up to ensure progressive development of international law and its codification. ${ }^{10}$ Article 15 of its Statute defines clearly the meaning of both processes: progressive development and codification of international law. ${ }^{11}$ Even though, 'the distinction between those two concepts might not be mutually exclusive, the Commission has proceeded on the basis of a composite idea of codification and progressive development. ${ }^{12}$. However, the Commission usually states in its works whether a particular provision reflects customary international law or whether it is a result of progressive development. Immunity of State officials from foreign criminal jurisdiction faced in this regard tangible challenges, as the methodological approach was not so clear. That is why during the work of the Commission, allusions were made with regard to the proper methodology of treatment of the topic itself in the reports of the Special rapporteur, as well as in written comments presented by States and in different papers presented by scholars.

The normative nucleus of immunity of state officials from foreign criminal jurisdiction is anchored entirely in customary international law as it reflects the traditional principle of sovereign equality of States and its procedural implication. Thus, there is a deeply rooted practice and opinio iuris of States regarding basic elements: why this immunity is accorded and who is entitled (State officials - head of States, prime ministers, ministers for foreign affairs). This is also confirmed by international case-law. ${ }^{13}$ Other elements are less clear in terms of customary law rules: to what extent immunity of jurisdiction applies to former State officials, whether there are any limits or exceptions, for example, with regard to peremptory norms violations, what are procedural aspects etc. If methodological concerns were

10 Article 1 of the Statute of International Law Commission, Adopted by the General Assembly in resolution 174 (II) of 21 November 1947.

11 Following Articles of ILC Statute regulate the process of the work for both approaches.

12 About the Commission, Methods of work: https://legal.un.org/ilc/methods.shtml, accessed 28 June 2021.

13 ICJ Arrest Warrant case (DRC v. Belgium), ICJ Certain Questions of Mutual Assistance in Criminal Matters (Djibouti v. France), etc. 
not discussed in the first ILC Special rapporteur's reports (R. Kolodkin) ${ }^{\mathbf{1 4}}$, the second Special rapporteur (Ms. Hernández) focused directly on that matter. Therefore, different debates on methodology occurred within the Commission, where voices for lex lata approach reflecting only customary international law collided with voices for lex ferenda approach promoting progressive development of international law. Finally, the Commission expressed the view that 'the approach to the topic must be balanced in order to weigh the principle of immunity against the need to combat impunity. ${ }^{15}$ ' Reactions of States voiced basically the same considerations as those previously discussed within the Commission. Some States wanted to exclude the concept of progressive development with respect to the topic; others opted for a combination of both concepts; other groups of States wanted the Commission to specify draft Articles which are the results of progressive development; 'some States also used the term 'new law' to describe a situation different from progressive development and codification, even alleging that the Commission was using this technique not envisaged in its Statute. ${ }^{16}$ ' 'Methodological flaws and drawbacks' were mentioned as well in the doctrine. ${ }^{17}$ It is however evident, that the declared methodological approach consisting in combining both concepts does not entirely correspond to the real method used by the Special rapporteur in her reports. In her proposals, she maintains rather the method portraying examples of State practice and the opinio iuris, referring also to the caselaw of international tribunals even for rules which are not of customary character. $^{18}$

14 R. Kolodkin viewed the topic immunity as an institution grounded in customary international law only, so he did not raise any concerns about the methodological approach in this regard.

15 (A/CN.4/654), para. 37.

16 Sixth report, A/CN.4/722, para. 18.

17 SHEN Quinin, Methodological flaws in the ILC' study on exceptions to immunity ratione materiae of state officials from foreign criminal jurisdiction. In: Symposium on the Present and Future of Foreign Official Immunity.

18 One could mention that this methodological ambiguity of Special rapporteur's report is amplified also by the fact that she uses examples which do not differentiate between the institute of State immunity and the institute of foreign official immunity. 


\section{Limitations and exceptions}

As it was mentioned earlier, the normative nucleus of the concept of immunity of state officials from foreign criminal jurisdiction is grounded in customary international law. Limitations and exceptions ${ }^{19}$ to the rule of immunity lie, on the other hand, rather in the group of (soft) rules of non-customary character and reflect a certain current stream, to wit 'humanization of international law' ${ }^{20}$ and 'the need to combat impunity' ${ }^{21}$. The idea that immunity from criminal jurisdiction should not be applicable for State officials in the situation of (mass) violations of important rules of international law is not a new one in modern international law. One could remember Article 227 of the 1919 Versailles Treaty allowing Allied powers the public accusation of German Emperor William II. And thus, many are examples of non-applicability of criminal immunity for State officials in the case of international criminal tribunals. ${ }^{22}$ On the other hand, when it comes to immunity from foreign criminal jurisdiction, examples are scarce. Here to be recalled especially is the Pinochet case, where the British House of Lords had to deal with a question as to whether there is an immunity applicable to former heads of State in the situation of massive violations of human rights; ${ }^{23}$ or, the ICJ Jurisdictional Immunity of State case (Germany v. Italy, Greece intervening) where the International Court of Justice was asked on conflicts of peremptory norms and norms regarding State

19 We do maintain in this note the terminology ('limitations and exceptions') presented by the Special Rapporteur already in the 4th report and kept thereof in the subsequent texts and documents of the ILC. According to the Special rapporteur, limitations and exceptions represent a single category of situations where the immunity of State officials before foreign criminal tribunals does not operate. However, she differentiates in theory between 'limitations' which are within and 'exceptions' which are without the boundaries of the concept. (Cf. Sixth report, A/CN.4/722, par. 170.) Limitations can be understood as 'absence of immunity', and exception as 'exclusion of existing immunity' - cf. A/72/10 - ILC Commentary to the draft Article 7, paragraph 1, para. 12 of the Commentary.

20 Cf. i.e. Meron, The Humanization of International Law, 2006;Peters, Beyond Human Rights. The Legal Status of the Individual in International Law, 2.

${ }_{21}$ Cf. Footnote ${ }^{\circ} 10$.

22 ICTY, ICTR and ICC Statutes.

${ }^{23}$ Regina v. Bartle and the Commissioner of Police for the Metropolis and others ex parte Pinochet. 
immunity. In both cases, neither House of Lords nor the ICJ decided that ius cogens should prevail over immunity from jurisdiction.

In 2016, the Special rapporteur, Ms. Escobar Hernández presented in her report deep considerations about limitations and exceptions to the immunity of State officials from foreign criminal jurisdiction. ${ }^{24}$ As it was pointed out, the methodological approach of the Special rapporteur (and later on the Commission ${ }^{25}$ ) with respect to this issue has been subject to critique among some members of the ILC, and elicited opposing reactions from certain States (in the UN GA Sixth Committee or in following written positions by $\operatorname{States}^{26}$ ). After presenting the legislative practices of States and judicial practices at international and national levels, the Special rapporteur analysed different theoretical concepts and approaches (e.g. methodology, legal nature of immunities, i.e. relation between immunity and jurisdiction, relation between immunity and responsibility, relation between State immunity and immunity of State officials). With respect to proper limitations and exceptions to immunity of state officials from foreign criminal jurisdictions, it is worth noting that both the Special rapporteur and members of the ILC came to a clear conclusion that there was neither theoretical support nor evidence of State practice for limitations or exceptions to immunity ratione personae. Thus, limitations and exceptions are not applicable for State officials during their term, but can be applicable only thereafter. ${ }^{27}$ If there are any situations where the immunity of State officials should not apply, those are only ratione materiae. The Special rapporteur adopted a rather broad approach ${ }^{28}$ considering not

24 It should be noted here that the second report presented by the first Special rapporteur, R. Kolodkin presented conclusions that in contemporary international law there is no customary international norm (nor a trend) on exceptions to immunity. ' $\mathrm{He}$ added that further restrictions on immunity, even de lege ferenda, were not desirable, since they could impair the stability of international relations; he also questioned their effect on efforts to combat impunity'. (Cf. Second report by R. Kolodkin presented in 2011 - Document A/CN.4/631, paras. 91-92).

25 ILC Report A/71/10, paras. 211-220 - Comments on methodological and conceptual issues raised in the fifth report.

${ }^{26}$ For example the reaction of the Permanent Mission to the UN in New York https://legal.un.org/ilc/sessions/70/pdfs/english/iso_austria.pdf.

27 The concept of limitations and exceptions of immunities ratione personnae does not apply before international criminal tribunals. Cf. for example, the Article 27 of International Criminal Court Statute.

28 In her 2016 report, the Special rapporteur proposed a draft to Article 7: Draft Article 7 Crimes in respect of which immunity does not apply: 1. Immunity shall not 
only international crimes as such limitations, but included also corruption and 'territorial tort exception'. Debate arose over the question to what extent, for example, corruption could be assessed as an act performed in official capacity. ${ }^{29}$ The same positions were expressed by some States in their written comments. ${ }^{30}$

The Commission, during its session in 2017 finally adopted six crimes under international law with respect of which immunity shall not apply: crime of genocide, crimes against humanity, war crimes, crime of apartheid, torture and enforced disappearance. The first three crimes are listed in Article 5 of the ICC Statute, ${ }^{31}$ the other three being considered by the Commission are listed 'as a separate category'. ${ }^{32}$ Even though all three are mentioned in Article 7 of ICC Statute under the crime of genocide definition, they fall as well under special international conventions ${ }^{33}$ and as separately mentioned, they do not require the mens rea of widespread and systematic attack directed against a civilian population as crimes against humanity do. The debate on draft Article 7 was very intensive, ${ }^{34}$ but the final text was provisionally adopted by the Commission by voting. ${ }^{35}$

apply in relation to the following crimes: (i) Genocide, crimes against humanity, war crimes, torture and enforced disappearances; (ii) Corruption-related crimes; (iii) Crimes that cause harm to persons, including death and serious injury, or to property, when such crimes are committed in the territory of the forum State and the State official is present in said territory at the time that such crimes are committed.

29 ILC Report A/71/10, para. 243.

30 Quite a similar approach was taken with respect to the crime of espionage which to the contrary to corruption is perpetrated on behalf of a State (in an official capacity). Espionage was not included to the list of crimes where immunity does not apply. Cf. https://legal.un.org/ilc/sessions/71/pdfs/english/iso_netherlands.pdf.

31 'The Commission decided not to include the crime of aggression at this time' because of the nature of this crime. Cf. A/72/10 - ILC Commentary to the draft Article 7, paragraph 1 , para. 18 of the Commentary.

32 Ibid. Para. 19 of the Commentary.

331973 International Convention on the Suppression and Punishment of the Crime of Apartheid, 1984 Convention against Torture and Other Cruel, Inhuman or Degrading Treatment or Punishment, 2006 International Convention for the Protection of All Persons from Enforced Disappearance.

34 Discussions on the content of the draft Article 7 and link with procedural aspects went on as well during the debates on sixth and seventh reports by the Special rapporteur.

35 Voting is rather an unusual method of adoption of a provisional text drafted by a Drafting committee. The text of the Article 7 has been adopted with 21 votes in favour, 8 votes against and 1 abstention. 


\section{Latest development}

With the issue of limitations and exceptions to immunities of State officials from foreign criminal jurisdiction, depicted in the previous section, the Special Rapporteur concluded the work on material aspects of the topic pursued in her first five reports and debated then by the Commission. From 2018 onwards, Ms. Hernandez focused on procedural aspects of the involvement of jurisdictional immunities of State officials, dedicating the last three reports to this. The Articles prepared on the basis of these reports form 'Part four' of the draft proposal on 'Procedural provisions and safeguards'. From the point of view of the methodology, this part relies on progressive development ${ }^{36}$ or de lege ferenda proposals.

Beginning with the rule that the competent authorities of the forum State have to consider the immunity as soon as they became aware of potential involvement of a foreign official in the criminal proceedings (Article 8), the procedural rules drafted by the Special Rapporteur then cover such topics as determination, invocation or waiver of immunity (Articles 9-11), exchange of information between the forum State and the State of the official (Article 13), rules for the transfer of proceedings (Article 14), and the obligation of a forum State to notify the State of the official that the official may be subject to the exercise of criminal jurisdiction (Article 12). Special provision of the draft Article 16 is devoted to an obligation to treat the State official in a fair and impartial way. These procedural safeguards are conceived as general rules for all situations involving possible consideration of immunity by a forum State. A question thus arose, among the members of the ILC, whether and to what extent these procedural rules and safeguards apply to limitations and exceptions to the rule of immunity (draft Article 7). 'Some members emphasized the paramount importance of designing specific procedural safeguards to address concerns regarding the application of draft Article $7^{37}$. Thus, the Commission recommended to clarify explicitly the applicability of procedural rules to the draft Article 7 'and to formulate specific safeguards

36 Even though the sixth and seventh report by the Special rapporteur provides 'a rich and detailed review and analysis of State practice'. Cf. A/74/10 - ILC report, para. 149.

A/74/10 - ILC report, para. 151. 
in relation to [it]. ${ }^{38}$ Other comments, suggestions and proposals were made with respect to specific draft Articles 8 to $16 .^{39}$

In the last report presented in April 2020, the Special rapporteur concentrated on the question of how the existence and activity of international criminal tribunals influences the concept of immunity of State officials from foreign criminal jurisdiction. Since the beginning of the work of Commission, both Special rapporteurs and ILC itself have emphasized that the immunity of State officials before international criminal tribunals does not fall within the scope of the topic, because international criminal jurisdiction has a special legal regime for treating the official capacity of perpetrators. ${ }^{40}$

However, while that it is true, [says the Special rapporteur], it is also true that immunity from foreign criminal jurisdiction does not operate in the abstract, outside the new reality represented by international criminal tribunals established to prosecute the most serious crimes of concern to the international community. ${ }^{41}$

As those crimes may also be committed by State officials, the Special Rapporteur held that the Commission could not finish the work on the topic without examining the interaction between foreign criminal jurisdiction and international criminal jurisdiction. Both concepts interrelate with each other mainly ${ }^{42}$ via the procedural aspects of cooperation between national criminal tribunals and international criminal tribunals. The utmost importance of this relationship has manifested itself during the AlBashir 'saga,' ${ }^{43}$ when different States refused to surrender Omar Al-Bashir,

38 Ibid. para. 152.

39 Ibid. paras. 156-179.

40 For example, Article 27(1) of ICC Statute says: 'This Statute shall apply equally to all persons without any distinction based on official capacity. In particular, official capacity as a Head of State or Government, a member of a Government or parliament, an elected representative or a government official shall in no case exempt a person from criminal responsibility under this Statute, nor shall it, in and of itself, constitute a ground for reduction of sentence.'

41 Eighth report on Immunity of State officials from foreign criminal jurisdiction. A/CN.4/739, para. 13.

42 The Special rapporteur highlighted, in her previous reports, as well, the common material aspects of 'acts performed in an official capacity' and 'limitations and exceptions to immunity' that might create a relationship between foreign criminal jurisdiction and international criminal jurisdiction.

${ }^{43}$ Svaček, 'Al-Bashir and the ICC - Tag, Hide-and-Seek...or Rather Blind Man's Bluff?', 177-190. 
then on-going Sudanese president, to the International Criminal Court where he was facing indictments on war crimes, crimes against humanity and the crime of genocide. In 2019, the ICC Appeals Chamber ruled on the appeal brought by Jordan against the decision on non-compliance with the ICC in re Al-Bashir. ${ }^{44}$ In its judgement, confirming the Pre-Trial Chamber decision, the ICC Appeals chamber held that by not arresting Omar AlBashir and by not surrendering him to the ICC, Jordan had failed to fulfil its obligation to cooperate with ICC. ${ }^{45}$

The Special rapporteur decided, with the consent of the Commission, to refrain from preparing a specific report on this ICC judgment, its assessment being beyond the ILC mandate. Nevertheless, she analysed the decision and extracted from it five ICC's findings related to the subject matter of immunity of State officials. According to her evaluation, two of them do not conflict with the work of the Commission, ${ }^{46}$ while the rest might have important implication for the concept of foreign criminal jurisdiction. ${ }^{47}$ She especially found the fifth finding, i. e. that 'the requested Party is not arresting the State official in order to prosecute him before national courts but to lend assistance to International Criminal Court' might provoke a greater debate. ${ }^{48}$ It is evident that the obligation to cooperate with the International Criminal Court - which arises for contracting parties from the ICC Statute ${ }^{49}$ - is a lex specialis to general obligations under international

44 ICC-02/05-01/09-397, 6 May 2019.

45 The ICC ruled also that the Article 27(2) of the ICC Statute on immunities not being a bar for the Court jurisdiction reflects the status of international customary law.

46 1. 'National tribunals and the International Criminal Court are subject to different rules with regard to immunity: while immunity of State officials may be invoked before a foreign criminal court, it cannot be invoked before the Court', and 2. 'Heads of State enjoy immunity before the national criminal tribunals of a third State, but not before international criminal'. Cf. A/CN.4/739, para. 24.

47 3. 'States parties to the Rome Statute have an obligation to cooperate fully with the International Criminal Court, including by arresting and surrendering persons accused of committing crimes that fall within the jurisdiction of the Court', 4. 'The obligation to cooperate is linked to Article 27 of the [ICC] Statute, which creates both vertical effects (jurisdiction of the International Criminal Court) and horizontal effects (jurisdiction of national courts)' and 5. 'In complying with the Court's request for cooperation, the requested State Party is not proceeding to arrest the Head of State in order to prosecute him or her before the courts of the requested State Party, it is only lending assistance to the Court in its exercise of the Court's jurisdiction'. Cf. A/CN.4/739, para. 24.

${ }^{48}$ Ibid. para. 26.

49 There are more than 120 contracting parties to the ICC Statute. 
customary laws. Furthermore, 'many Commission members and States in the Sixth Committee have pointed to the relevance of international criminal tribunals in the fight against impunity' ${ }^{50}$ and noted that the work of the Commission should not 'undermine the substantive and institutional norms developed in that area'. ${ }^{51}$ The Special rapporteur, thus, had to find a way how to conciliate, on the one hand, this important special treaty law regime created for international criminal tribunals, and, on the other hand, the general regime within the area of national (foreign) criminal jurisdiction. To stress the importance and the speciality of (especially) the ICC position within the topic under ILC consideration would mean to add many different special rules applicable in a conflict between international and foreign criminal jurisdiction. The Special Rapporteur chose a different approach. In her last report, 'preserv[ing] the rightful place of international criminal tribunals in contemporary international law, ${ }^{52}$ she referred to the International Court of Justice judgement in the Arrest warrant case, where the court identified such tribunals as an alternative means of avoiding impunity in cases where the criminal courts of a State cannot exercise jurisdiction. ${ }^{53}$ And thus, Mrs. Hernandez presented a 'without prejudice' clause to solve this specific situation. Draft Article 18 reads: 'The present draft Articles are without prejudice to the rules governing the functioning of international criminal tribunals.' This draft Article will be discussed during the next ILC session in May 2021. However, we can already observe that the formulation is rather general. It is nevertheless difficult to anticipate whether or not the wording 'rules governing the 'functioning' of international criminal tribunals' will leave space for doubts or debate amidst members of the Commission.

Besides the issue on relationship between foreign criminal jurisdiction and international criminal jurisdiction, the Special Rapporteur focused her attention on the settlement of international disputes. During the discussion in 2019, the Commission was not unanimous whether and to what extent the Special Rapporteur should pursue this subject because, back then, it was unclear what form the work of the Commission would take. Some members pointed out that any provision on the settlement

50 Cf. A/CN.4/739, para. 30.

51 Ibid.

52 Ibid. para. 31.

53 Arrest Warrant of 11 April 2000 (Democratic Republic of the Congo v. Belgium), Judgement, I.C.J. Reports 2002, p. 3 et seq., especially pp. 25 and 26, para. 61. 
of disputes is more likely to be included in international treaties than in draft Articles. On the other hand, in other recent works presented by the Commission such provision was adopted. ${ }^{54}$ The majority of Commission members who voiced their position in the debate were in favour of including the provision on dispute settlement mechanisms. ${ }^{55}$ Thus, opting for the strategy to incorporate said provision to draft Articles on the first reading of the Commission, rather than leave it to the second one, the Special rapporteur proposed a draft Article on dispute settlement in her last report - the draft Article 17 - Settlement of disputes follows in the line of the draft Article 15 - Consultation, which stipulates the obligation of both States involved in the procedure to consult on matters concerning the determination of the immunity. The draft Article 17 is framed in gradual possibilities, meaning that in case of unsatisfactorily consultations, 'the two States shall endeavour to settle the dispute [...] through negotiations'. If negotiation fails to difference of opinion, either State may suggest referring the dispute before arbitration or the International Court of Justice. If such a referral happens, 'the forum State shall suspend the exercise of its jurisdiction until the competent organ issues a final ruling'.

In the last section of her report presented in April 2020, Mrs. Hernandez treated the issue of 'recommended good practices'. The suggestion to include 'good practices' which States could be recommended to adopt ${ }^{56}$ ensued from a finding that

in a number of cases, the State organs responsible for adopting decisions in this regard were not familiar with the particular problem of immunity in international law, its relationship with the fundamental principles of international law and the impact that decisions concerning the immunity of a foreign official might have on the State's international relations. ${ }^{576}$

The intention was to prepare a sort of practical guide for States and their State organs to instruct them how to proceed in a situation where the immunity of a State official is involved, and requires them to consider, determine, invoke, or waive the immunity, to request or supply the information relevant for the assessment of immunity, or to resolve

54 Peremptory norms of general international law - ius cogens (Conclusion 21) and Crimes against humanity (Article 15).

55 A/CN.4/739, para. 34.

56 Ibid. para. 55.

57 Ibid. 
other related matters. In the end, the Special Rapporteur rejected this notion/idea - arguing that nothing prevents the States themselves from preparing such a manual for their State organs.

\section{Conclusion}

Presenting her eighth report on immunity of State officials from foreign criminal jurisdiction in April 2020, the Special Rapporteur Ms. Hernandez has concluded her research and work on the topic. After all her endeavours, she had expressed her hopes that, after debating both on the lastly presented draft Articles and on those still pending before ILC Drafting Committee, the Commission will be able to adopt the draft Articles on the first reading. In the course of more than 13 years, the Commission have carried out a very fruitful work consisting not only in the codification of already existing customary rules with respect to immunity ratione personae, but also in promoting its progressive development by formulating the concept of limitations and exceptions to immunity and portraying procedural rules applicable by a forum State or the State of the official. Since the very beginning of work on the topic, different States responded to the invitation of the Commission and presented their written observations, either within the UN Sixth Committee or without, and reported on their national practice. Some States supported the approach of progressive development embraced by the ILC, others were rather reluctant. This shows that, almost certainly, not all States will adhere to the same position in commenting and assessing the final version of draft Articles on immunity of State officials. In the end, as things will progress, the draft Articles and especially de lege ferenda provisions will crystallize in various State practice and in the case-law of international tribunals. 


\section{Bibliography}

1. Meron, Theodor, The Humanization of International Law, The Hague Academy of International Law. Leiden: Martinus Nijhoff Publishers, 2006.

2. Peters, Anne, Beyond Human Rights. The Legal Status of the Individual in International Law. Cambridge: Cambridge University Press, 2016.

3. Svaček, Ondřej, "Al-Bashir and the ICC - Tag, Hide-and-Seek...or Rather Blind Man's Bluff?' In The Rome Statute of the ICC at Its Twentieth Anniversary, edited by Pavel Šturma. Leiden: BRILL, 2019. 